\title{
Erratum
}

\section{Before Hegemony: Adam Smith, American Independence, and the Origins of the First Era of Globalization-Erratum}

\author{
James Ashley Morrison
}

doi: 10.1017/S0020818312000148, Published by Cambridge University Press, August 2012

Page 423, third full paragraph: The sentence that reads "In practice, though, scholars of international politics have privileged conciseness and generalizability at the expense of accuracy" should say instead "In practice, though, scholars of international politics have privileged parsimony and generalizability at the expense of accuracy." (Morrison 2012)

Morrison, James A. (August, 2012) Before Hegemony: Adam Smith, American Independence, and the Origins of the First Era of Globalization. International Organization, 66(3), p423. 